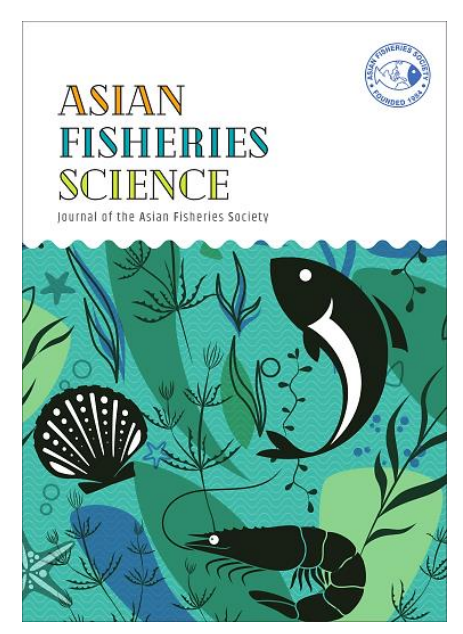

(ㄷ) Asian Fisheries Society

ISSN: 0116-6514

E-ISSN: 2073-3720

https://doi.org/10.33997/j.afs.2020.33.4.004

\section{Diversity of Vibrio Species' and Their Antibiotic Resistance Patterns in Black Tiger Shrimp Penaeus monodon Fabricius, 1798 Cultured in South-West Region of Bangladesh}

MOHAMMAD SHAMSUR RAHMAN* ${ }^{*}$ MD MOSTAVI ENAN ESHIK, NUSRAT JAHAN PUNOM, MD. MINHAZUL ABEDIN, MST KHADIZA BEGUM

Aquatic Animal Health Group, Department of Fisheries, University of Dhaka, Dhaka 1000, Bangladesh

*E-mail: shamsur@du.ac.bd |Received: 09/07/2020; Accepted: 09/12/2020

\begin{abstract}
Shrimp aquaculture industry comprises $15 \%$ of the internationally traded seafood products targeted for human consumption. Diseases of shrimp have caused severe economic losses to the aquaculture industry. Among pathogenic bacteria, several Vibrio species known as shrimp pathogens are also human pathogens. This study was conducted to identify the incidence of diversified Vibrio species in the shrimp Penaeus monodon Fabricius, 1798 farms in Bangladesh. Different Vibrio selective media were used for primary isolation and 16S rRNA gene amplicons were sequenced, followed by phylogenetic analysis. The Vibrio strains were also tested against twelve antibiotics. Two strains V32 and V38 showed $99.93 \%$ similarity with Vibrio azureus whereas V9 and V33 showed $100 \%$ identity with Vibrio fluvialis. Comparison of 16S rRNA gene sequence of V37 with sequences from GenBank identified the strain as Vibrio xuii. The phylogenetic tree indicates that V24, V26, V34 and V35 are closely related with Vibrio parahaemolyticus. The strains V28 and V31 were identified as Vibrio vulnificus. One strain of Vibrio cholerae was also identified. Moreover, V22 was identified as Photobacterium damselae subsp. damselae, and V25 as Aeromonas hydrophila. Twelve strains of Vibrio were resistant to amoxycillin, whereas all 16 bacterial isolates showed sensitivity to nitrofurantoin, sulphamethoxazole, chloramphenicol, ciprofloxacin and tetracycline. Multidrug resistance was observed in three isolates viz. V28, V32 and V35 which were identified as V. vulnificus, V. azureus and V. parahaemolyticus, respectively having MAR index of 0.25. These findings might have potential applications in controlling shrimp and human pathogenic vibrios in the farming regions.
\end{abstract}

Keywords: shrimp aquaculture, vibrios, $16 \mathrm{~S}$ rRNA gene, antibiogram, amoxycillin

\section{Introduction}

Aquaculture is the significant production sector for high-protein aquatic animal food, especially shrimp products that have occupied a huge market share worldwide (Hasan, 2001). Due to high market demand, many countries of the world have been expanding their shrimp farming areas, and shifted from traditional to more intensive culture practices to maximise production. In 2017, it was reported that $60.5 \%$ (5.5 million tons) of the total shrimp and prawn production were from aquaculture where Penaeus monodon Fabricius, 1798 accounted for 0.74 million tons (FAO, 2019). The export of shrimp and prawns in 2017 accounted for more than 4.4 million tons which share $6.72 \%$ of the total exports (FAO, 2019). Bangladesh is among the top ten producers of marine crustacean aquaculture besides China, Vietnam, and Indonesia (FAO, 2018).

In an analysis by Darryl Jory, global shrimp production was expected to be $15 \%$ less in 2015 than in 2011 due to severe disease occurrences in shrimp farms (Jory, 2014). Due to the intensification of the shrimp culture industry, emerging diseases outbreaks have increased and caused significant socio-economic impacts in affected areas. Losses due to the diseases are one of the major indicators of the current unsustainable system of shrimp farming (Hossain and Hasan, 2017).

Bacteria are commonly known to cause various endemic and epidemic diseases of shrimp (Lightner, 
1996). Bacteria of the genus Vibrio are ubiquitous in the marine and estuarine ecosystems where shrimp grow naturally and are also farmed in the brackish water (Ruangpan and Kitao, 1991). Most of the bacteria that caused infections to shrimp are generally opportunistic pathogens causing disease whenever the shrimps are in stressed condition (Lightner, 1993). Among one hundred and thirty species of vibrios that have been described, twelve were classified as human pathogens that mostly causes food- or water-borne diseases. These include Vibrio cholerae that is the primary cause of diarrhoea, Vibrio parahaemolyticus causing seafood-borne gastroenteritis and Vibrio vulnificus responsible for $95 \%$ of all deaths from seafood consumption (Thompson et al., 2006). These vibrios are the indigenous bacterial flora of shrimp and the culture water (Otta et al., 1999), but they are secondary or opportunistic pathogens that sometimes cause $100 \%$ mortality of infected shrimp (Lightner, 1988).

In addition, some vibrios may cause disease of aquatic animals and as well as of human. In humans, vibrios usually cause wound infections and gastroenteritis. Austin (2010) has categorised V. cholerae, V. parahaemolyticus and $V$. vulnificus as higher risk organisms for zoonoses, whereas Grimontia (=Vibrio) hollisae, Photobacterium (=Vibrio) damselae subsp. damselae, V. alginolyticus, V. harveyi, V. fluvialis and V. mimicus have been classified as lower risk organisms.

Members of the genus Vibrio consist of a significant portion of the microbiota in shrimp farming environments. The high stocking density of shrimps and huge artificial feed supply support the proliferation of vibrios in these farming systems. As vibrios have been known to cause large-scale mortality and great economic losses in the aquaculture industry (Gopal et al., 2005), their control necessitates prophylactic and therapeutic use of antibiotics (Devi et al., 2009; Manjusha and Sarita, 2011). The excessive application of antibiotics has caused the threat of antimicrobial resistance (AMR) traits in vibrios (Sudha et al., 2014; Letchumanan et al., 2015). In addition, the use of antibiotics in shrimp farming is very well-known, but due to ignorance, little is done to change the practice at the farm. Moreover, cultured shrimp can act as vehicles of antibiotic resistant vibrios, especially to $\beta$-lactam and tetracycline (Costa et al., 2015). Due to the international trade of live shrimp and its products, shrimp aquaculture can play a major role in the dissemination of antimicrobial resistance globally (Thornber et al., 2020). So, it is necessary to detect the Vibrio spp. with antibiotic resistance in shrimp farming areas.

Identification of the pathogenic bacteria up to the species level is crucial in disease epidemiology to trace the exact source of the new outbreak and to formulate strategies to minimise the losses due to disease. But the classical method of detecting bacteria based on phenotypes and biochemical reactions is not as accurate as identification through molecular approach. Moreover, traditional identification techniques are time consuming and ambiguous. Ransangan and Mustafa (2009) suggested that only the biochemical characteristics cannot be used to accurately identify disease causing bacteria in aquaculture. Instead, 16S rRNA gene sequence can be used to identify non-popular, phenotypically variant strains, and can lead to the identification of novel pathogenic strains and non-cultured bacteria (Clarridge, 2004). Furthermore, the $16 S$ rRNA gene sequence (about 1500 bp) is large enough for bioinformatics purposes (Patel, 2001). Therefore, in this study, 16S rRNA gene sequencing was employed for the identification of Vibrio isolates.

In Bangladesh, the shrimp aquaculture industry has emerged as a sector for foreign exchange earnings. Due to the occurrences of several diseases in shrimp, especially vibriosis, the sector has been facing serious production losses annually. Most of the vibrios are autochthonous inhabitants of marine water and this water is used for shrimp aquaculture. Vibrio spp. are opportunistic pathogens that cause serious disease outbreaks when it's found suitable host such as shrimp.

The objective of the work was to investigate the diversity of Vibrio species in the cultured shrimp $P$. monodon of Bangladesh. In addition, the antibiotic resistance pattern of representative bacterial isolates was also investigated.

\section{Materials and Methods}

\section{Sample collection}

In the present study, shrimp samples were collected using cast net from 16 farms in Bagerhat and Satkhira districts of Khulna division (Fig. 1). The freshly caught shrimp samples were kept in an icebox maintaining at $-4^{\circ} \mathrm{C}$ and transferred to the laboratory. All samples were collected following the method of American Public Health Association (APHA, 1998).

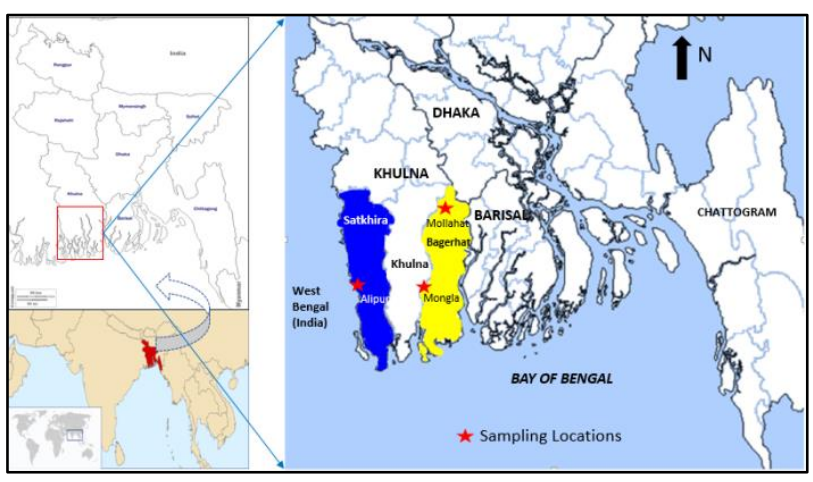

Fig. 1. Location of farms investigated for Vibrio diversity in Satkhira and Bagerhat districts of Khulna Division, Bangladesh. 


\section{Isolation of Vibrio spp. from shrimp samples}

Physiological saline $(0.85 \% \mathrm{NaCl})$ was added to shrimp samples (hepatopancreas and whole shrimp) and the samples were ground in a mortar aseptically. Alkaline peptone water (APW) was used for the enrichment of the samples in order to provide a suitable environment for Vibrio species' to grow and reach a detectable level for the presumptive identification. Then $1 \mathrm{~mL}$ of blended solution from each sample was taken in $9 \mathrm{~mL}$ APW in a test tube. These tubes were kept in an incubator at $37^{\circ} \mathrm{C}$ for 6 to $24 \mathrm{~h}$.

After the incubation period, 2-3 loop full of bacteria were transferred from APW tube to TCBS (Oxoid, UK)/ HiChrome (HiMedia, India)/ CHROMagar (France) vibrio media aseptically and then streaked. The streaked TCBS/HiChrome/CHROMagar plates were incubated at $37^{\circ} \mathrm{C}$ for $24 \mathrm{~h}$. The single colonies from agar plates were further screened on their morphological appearance and only isolates that showed variations were stored in Luria-Bertani (LB) broth supplemented with $30 \%$ glycerol at $-80^{\circ} \mathrm{C}$ for further use.

\section{Molecular identification and phylogenetic analysis using 16 S rRNA gene sequences}

Heat extracted chromosomal DNA of the selected isolates were used for the amplification of partial 16S rRNA gene by Polymerase Chain Reaction (PCR) using the following primer pairs: 27F 5'AGAGTTTGATCCTGGCTCAG -3' and 1492R 5'CGGTTACCTTGTTACGACTT - 3' (Weisburg et al., 1991). Amplification was performed in a reaction volume of $25 \mu \mathrm{L}$ that comprises $12.5 \mu \mathrm{L}$ of Hot Start Colorless Master Mix, $1 \mu \mathrm{L}$ of DNA template, $9.5 \mu \mathrm{L}$ of Nucleasefree water, $1 \mu \mathrm{L}$ of forward and reverse primers. PCR amplification was performed in an oil-free thermal cycler (Applied Biosystems 2720 Thermal Cycler) with the following program: $95{ }^{\circ} \mathrm{C}$ for $5 \mathrm{~min}$ for denaturation, then 32 cycles at $95^{\circ} \mathrm{C}$ for $30 \mathrm{sec}, 48^{\circ} \mathrm{C}$ for $30 \mathrm{sec}$ and $72{ }^{\circ} \mathrm{C}$ for $1 \mathrm{~min} 30 \mathrm{sec}$, followed by a final extension step at $72{ }^{\circ} \mathrm{C}$ for 5 min. Successful amplification of the desired segment was visualised by running the PCR products in $1 \%$ agarose gel (w/v) stained with $2 \mu \mathrm{L}$ of ethidium bromide (H5041, Promega, USA). Alphalmager mini gel documentation system (ProteinSimple, USA) was used to observe and photograph DNA bands (Fig. 2). Before sending for sequencing, amplified DNA fragments were further purified with the Wizard PCR SV Gel and PCR clean-up system kit (Promega, USA) according to the manufacturer's instruction.

The PCR products were sent to First Base Laboratories Sdn. Bhd., Malaysia, for sequencing where BigDye Terminator v 3.1 Cycle Sequencing Kit was used according to manufacturer's instruction. The sequences were obtained by capillary electrophoresis using ABI Genetic Analyzer (Applied Biosystem, USA). Both forward and reverse sequences were done for all the 16 representative bacterial isolates.

The 16S rRNA sequences of the bacterial isolates were compared with other sequences using Nucleotide BLAST (http://blast.ncbi.nlm.nih.gov) program in NCBI (National Center for Biotechnology Information) to determine the closest matched sequences in GenBank. From the scoring of relatedness shown in the search result, the best matched strains were considered as the identified isolates. MEGA $X$ was used for the comparative analysis of DNA sequence data which was used for reconstructing the phylogenetic tree of Vibrio species (Kumar et al., 2018).

\section{Antibiotic susceptibility test}

Pure culture of Vibrio isolates was grown in Muller Hinton broth, MHB (Oxoid, UK) for antibiotic sensitivity testing. Mueller Hinton agar (MHA) was used as solid media and the disc diffusion method was applied to check antibiotic susceptibility (Hudzicki, 2009). The antibiotics viz. amoxycillin $(10 \mu \mathrm{g})$, ampicillin $(10 \mu \mathrm{g})$ azithromycin $(15 \mu \mathrm{g})$, chloramphenicol (30 $\mu \mathrm{g})$ ciprofloxacin $(5 \mu \mathrm{g})$, erythromycin $(15 \mu \mathrm{g})$, gentamycin $(10 \mu \mathrm{g})$, kanamycin $(30 \mu \mathrm{g})$, nitrofurantoin $(300 \mu \mathrm{g})$, polymyxin B (300 unit), sulphamethoxazole $(25 \mu \mathrm{g})$ and tetracycline $(30 \mu \mathrm{g})$ were used in the present study. After enrichment in $\mathrm{MHB}$ for $18-24 \mathrm{~h}$ at $37{ }^{\circ} \mathrm{C}$, the cultures were streaked on MHA plates using a cotton swab. The antibiotic discs (Oxoid, UK) were placed on
$\begin{array}{llllllllll}M & \text { V24 } & \text { V26 } & \text { V28 } & \text { V31 } & \text { V32 } & \text { V33 } & \text { V35 } & \text { V38 }\end{array}$

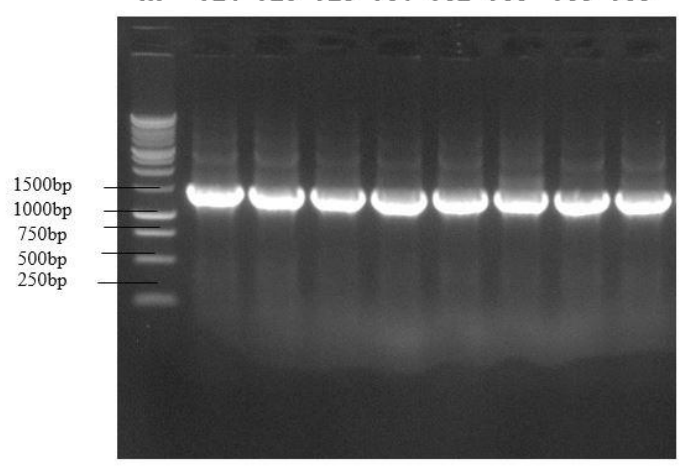

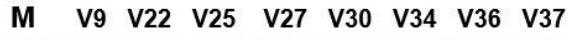

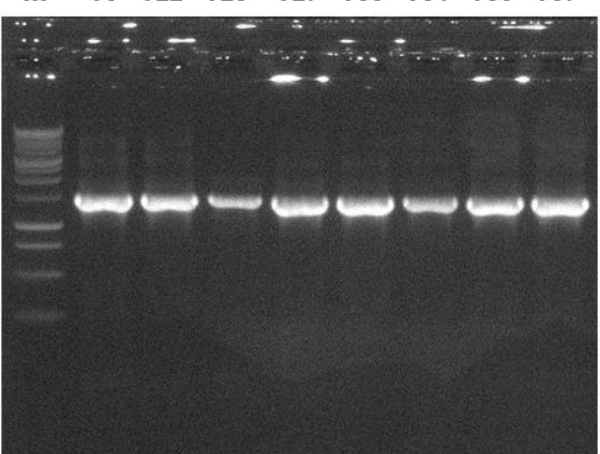

Fig. 2. Gel electrophoresis of $16 \mathrm{~S}$ rRNA gene PCR product using $27 \mathrm{~F} \& 1492 \mathrm{R}$ universal primers generated from 16 different bacterial isolates sampled from Penaeus monodon farms; $M$ denotes 1 kb DNA ladder (Marker). 
the agar surface with enough space to avoid overlapping of the inhibition zones. After $30 \mathrm{~min}$ of pre-diffusion time, the plates were incubated at $37^{\circ} \mathrm{C}$ for $18-24 \mathrm{~h}$. After the incubation period, the diameter of the inhibition zones was measured and compared with the interpretive chart of Performance Standards for Antimicrobial Disk Susceptibility Tests and classified as resistant, intermediate and sensitive (CLSI, 2009).

\section{Multiple antibiotic resistance (MAR) index of the studied strains}

The studied 16 isolates were observed for multiple antibiotic resistance (MAR) against 12 antibiotics. According to Schwarz et al. (2010), the bacterial strains resistant against three or more antibiotics can be considered as multidrug resistant strains. Following Krumperman (1983), the MAR index values of the bacterial isolates were calculated as: $a / b$; where ' $a$ ' represents the number of antibiotics the strain was resistant to and ' $b$ ' denotes the total number of antibiotics the strain was tested.

The reported sequences in this study have been deposited to the GenBank database under accession numbers MH244235 to MH244247.

\section{Results}

\section{Isolation of Vibrio spp. from shrimp samples}

A total of 38 isolates were isolated from three Vibrio selective media. Among them, 16 isolates were selected based on colony morphology and purified for detailed study towards molecular identification. Colonies of the selected isolates were found to be different in their form, size and colour (Table 1). Most of the selected colonies were entire, round and smooth in nature.

\section{Identification of bacterial isolates based on 16S rRNA gene sequence}

The identification of the 16 representative isolates (V9, V22, V24, V25, V26, V27, V28, V30, V31, V32, V33, V34, V35, V36, V37 and V38) based on 16S rRNA gene sequences through nucleotide BLAST of NCBI is summarised in Table 2. The sequences of isolates (except V30 and V36 due to noise in sequence) were matched with the strains presented in their respective following column. Table 2 also provides information about scoring viz. maximum score, percentage of query coverage, $E$ value and percentage of identity of the sequences with NCBI GenBank accession number of the matched sequences.

The amplified PCR products (Fig. 2) were sequenced and aligned with the 16S rRNA gene sequences available in GenBank. Most of the sequences showed $>99 \%$ homology and some of them showed $100 \%$ homology. Two strains V32 and V38 showed $99.93 \%$ identity with $V$. azureus strain $\mathrm{CHB}-23$. Both V9 and V33 strains showed $100 \%$ query coverage and identity with V. fluvialis strain LCB1. V28 and V31 showed $100 \%$ similarity with $V$. vulnificus strain CMCP6 and WN141012, respectively. On the other hand, V24, V26, V35 and V38 strains exhibited $99 \%$ query coverage and identity with $V$. parahaemolyticus, whereas V22 as Photobacterium damselae subsp. damselae CSMA-T3 and V25 as Aeromonas hydrophila strain I-T-1-1. V27 isolate showed $100 \%$ query coverage and $99.93 \%$ identity with V. cholerae strain 2011V-1043.

\section{Phylogenetic analysis}

Phylogenetic analysis performed by constructing the phylogenetic tree based on the partial 16S rRNA gene sequences of the representative 14 isolates using the neighbour-joining method confirmed the taxonomic position of the isolates (Fig. 3). The phylogenetic tree

Table 1. Sampling information and colony morphology of the 16 isolates suspected as Vibrio spp. isolated from shrimp Penaeus monodon samples.

\begin{tabular}{|c|c|c|c|c|c|c|c|}
\hline $\begin{array}{l}\text { Serial } \\
\text { No. }\end{array}$ & $\begin{array}{l}\text { Strain } \\
\text { ID }\end{array}$ & $\begin{array}{l}\text { Sample } \\
\text { ID }\end{array}$ & $\begin{array}{l}\text { Sampling } \\
\text { region }\end{array}$ & $\begin{array}{l}\text { Gher volume } \\
\text { (Acres) }\end{array}$ & $\begin{array}{l}\text { Culture } \\
\text { medium }\end{array}$ & $\begin{array}{l}\text { Culture } \\
\text { condition }\end{array}$ & $\begin{array}{l}\text { Colony } \\
\text { morphology }\end{array}$ \\
\hline 1 & V9 & $\mathrm{M} 2 \mathrm{H6}$ & Satkhira & 8 & TCBS & Direct plate & Yellow, large \\
\hline 2 & V22 & ShW1 & Satkhira & 6 & TCBS & Direct plate & Green, small \\
\hline 3 & V24 & ShW2 & Satkhira & 8 & TCBS & Direct plate & Greenish, medium \\
\hline 4 & V25 & AnW2 & Satkhira & 4 & TCBS & Direct plate & Greenish, medium \\
\hline 5 & V26 & AbW1 & Satkhira & 0.6 & TCBS & 6 h enrichment & Yellow, small \\
\hline 6 & V27 & AbW2 & Satkhira & 0.6 & TCBS & Direct plate & Yellow, Large \\
\hline 7 & V28 & BaW1 & Satkhira & 8 & TCBS & Direct plate & Yellow, small \\
\hline 8 & V30 & BaWM & Mongla & 1 & TCBS & 6 h enrichment & Yellow, small \\
\hline 9 & V31 & MiWB & Bagerhat & 2 & TCBS & 6 h enrichment & Yellow, small \\
\hline 10 & V32 & MiHB & Bagerhat & 2 & TCBS & 6 h enrichment & Yellow, small \\
\hline 11 & V33 & $\mathrm{JoHB}$ & Bagerhat & 4 & ChromAgar & Direct plate & Yellow, large \\
\hline 12 & V34 & AfWB & Bagerhat & 3 & ChromAgar & Direct plate & Yellow, small \\
\hline 13 & V35 & SeWB & Bagerhat & 3 & ChromAgar & Direct plate & Yellow, small \\
\hline 14 & V36 & MaHB & Bagerhat & 9 & TCBS & Direct plate & Green small \\
\hline 15 & V37 & ISHM & Mongla & 4 & HiChrome & 6 h enrichment & Turquoise, small \\
\hline 16 & V38 & JoWB & Bagerhat & 4 & HiChrome & $6 \mathrm{~h}$ enrichment & Turquoise, small \\
\hline
\end{tabular}




\begin{tabular}{|c|c|c|c|c|c|c|c|c|c|}
\hline $\begin{array}{l}\text { Serial } \\
\text { No. }\end{array}$ & $\begin{array}{l}\text { Isolates ID with } \\
\text { strain } \\
\text { designation }\end{array}$ & $\begin{array}{l}\text { Description of closest relative } \\
\text { (obtained from GenBank BLAST } \\
\text { search) }\end{array}$ & $\begin{array}{l}\text { Base } \\
\text { pairs } \\
\text { (bp) }\end{array}$ & $\begin{array}{l}\text { Max } \\
\text { score }\end{array}$ & $\begin{array}{l}\text { Query } \\
\text { coverage } \\
(\%)\end{array}$ & $\begin{array}{l}\mathrm{E} \\
\text { value }\end{array}$ & $\begin{array}{l}\text { Identity } \\
(\%)\end{array}$ & $\begin{array}{l}\text { Accession } \\
\text { number of } \\
\text { corresponding } \\
\text { sequence }\end{array}$ & $\begin{array}{l}\text { Accession } \\
\text { number of } \\
\text { strains } \\
\text { under } \\
\text { present } \\
\text { study }\end{array}$ \\
\hline 1 & Vg (msr1) & $\begin{array}{l}\text { Vibrio fluvialis } \\
\text { strain LCB1 }\end{array}$ & 1426 & 2634 & 100 & 0.0 & 100 & KC210808.1 & MH244235 \\
\hline 2 & V22 (msr2) & $\begin{array}{l}\text { Photobacterium damselae subsp. } \\
\text { damselae CSMA-T3 }\end{array}$ & 1422 & 2627 & 100 & 0.0 & 100 & MK482019.1 & MH244236 \\
\hline 3 & V24 (msr3) & $\begin{array}{l}\text { Vibrio parahaemolyticus } \\
\text { strain } \mathrm{CZN}-34\end{array}$ & 1424 & 2630 & 100 & 0.0 & 100 & KR347270.1 & MH244237 \\
\hline 4 & V25 (msr4) & $\begin{array}{l}\text { Aeromonas hydrophila } \\
\text { strain } 1-T-1-1\end{array}$ & 1417 & 2591 & 99 & 0.0 & 99.79 & KU570301.1 & MH244238 \\
\hline 5 & V26 (msr5) & $\begin{array}{l}\text { Vibrio parahaemolyticus } \\
\text { strain 20140829008-1 }\end{array}$ & 1425 & 2627 & 100 & 0.0 & 99.93 & СР034294.1 & MH244239 \\
\hline 6 & V27 (msr6) & $\begin{array}{l}\text { Vibrio cholerae } \\
\text { strain 2011V-1043 }\end{array}$ & 1419 & 2615 & 100 & 0.0 & 99.93 & СР046837.1 & MH244240 \\
\hline 7 & V28 (msr7) & $\begin{array}{l}\text { Vibrio vulnificus } \\
\text { strain CMCP6 }\end{array}$ & 1413 & 2610 & 100 & 0.0 & 100 & СР037931.1 & MH244241 \\
\hline 8 & V30 & Bad chromatogram & \multicolumn{6}{|c|}{ Excluded from identification } & - \\
\hline 9 & V31(msr8) & $\begin{array}{l}\text { Vibrio vulnificus } \\
\text { strain WN141012 }\end{array}$ & 1415 & 2614 & 100 & 0.0 & 100 & KU245729.1 & MH244242 \\
\hline 10 & V32 (msr9) & $\begin{array}{l}\text { Vibrio azureus } \\
\text { strain HHN-3 }\end{array}$ & 1425 & 2623 & 99 & 0.0 & 99.93 & KR270154.1 & MH244243 \\
\hline 11 & V33 (msr10) & $\begin{array}{l}\text { Vibrio fluvialis } \\
\text { strain LCB1 }\end{array}$ & 1423 & 2628 & 100 & 0.0 & 100 & KC210808.1 & MH244244 \\
\hline 12 & V34 (msr11) & $\begin{array}{l}\text { Vibrio parahaemolyticus } \\
\text { strain } 461\end{array}$ & 1427 & 2630 & 100 & 0.0 & 99.93 & JN188418.1 & MH244245 \\
\hline 13 & V35 (msr12) & $\begin{array}{l}\text { Vibrio parahaemolyticus } \\
\text { strain } \mathrm{CZN}-34\end{array}$ & 1424 & 2625 & 100 & 0.0 & 99.93 & KR347270.1 & MH244246 \\
\hline 14 & V36 & Bad chromatogram & \multicolumn{6}{|c|}{ Excluded from identification } & - \\
\hline 15 & V37 & $\begin{array}{l}\text { Vibrio xuii strain } 0104 \\
\text { (Not in full length) }\end{array}$ & 1008 & 1722 & 99 & 0.0 & 97.81 & KP236239.1 & - \\
\hline 16 & V38 (msr13) & $\begin{array}{l}\text { Vibrio azureus } \\
\text { strain } \mathrm{CHB}-23\end{array}$ & 1423 & 2623 & 100 & 0.0 & 99.93 & KR347286.1 & MH244247 \\
\hline
\end{tabular}

indicates that V32, V38, V24, V26, V35 and V36 were closely related to allocated strains $V$. azureus CHB-23 and $V$. parahaemolyticus strains $\mathrm{CZN}-34$. The phylogenetic tree further confirmed the taxonomic position of V25 supporting their similarity with the allocated strain A. hydrophila strain I-T-1-1, V27 as V. cholerae strain 2011V-1043 and, V28 and V31 as V. vulnificus WN141012. From the tree, it is found that V9 and V33 were closely related to V. fluvialis strain LCB1, while V37 strain is similar with V. xuii strain 0104.

The evolutionary history was inferred using the neighbour-joining method (Saitou and Nei, 1987). The optimal tree with the sum of branch length = 2.64045822 is shown. The percentage of replicate trees in which the associated taxa clustered together in the bootstrap test (1000 replicates) are shown next to the branches. The evolutionary distances were computed from the number of base substitutions per site using the maximum composite likelihood method (Tamura et al., 2004). The analysis involved 23 nucleotide sequences with 1508 positions in the final dataset. All ambiguous positions were removed for each sequence pair (pairwise deletion option). Green circular shape indicates the position of the studied strains.

\section{Antibiotic susceptibility test of bacterial strains of Vibrio spp.}

In the present study, 16 bacterial isolates were tested against 12 common antibiotics. Results of antibiotic susceptibility test are shown in Table 3 and Table 4. Except for four isolates (V25, V27, V30, V31), rest of the twelve strains were resistant to amoxycillin (10 $\mu \mathrm{g})$, whereas all 16 strains showed sensitivity to nitrofurantoin, sulphamethoxazole, chloramphenicol, ciprofloxacin and tetracycline. Among all strains, 11 strains of Vibrio showed sensitivity to kanamycin but five strains (V22, V28, V31, V32, and V36) were found intermediate to it. Moreover, 15 strains were found sensitive against azithromycin while only V33 exhibited an intermediate pattern. Among all the 16 strains, nine strains were found resistant to ampicillin. 


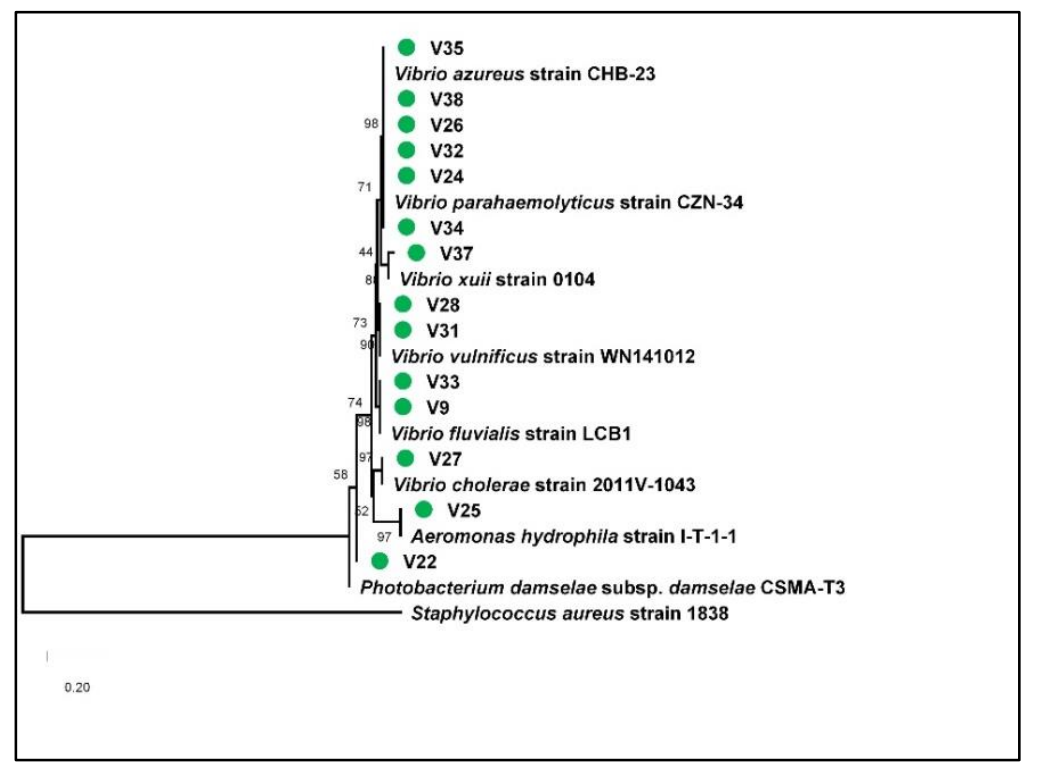

Fig. 3. Molecular phylogenetic analysis by neighbour-joining method using MEGA $X$ of representative 14 strains collected from Penaeus monodon farms.

Table 3. Results of antibiotic susceptibility test against 12 antibiotics for 16 bacterial isolates collected from Penaeus monodon farms.

\begin{tabular}{|c|c|c|c|c|}
\hline \multirow{2}{*}{ Isolate ID } & \multirow{2}{*}{ Identified species } & \multicolumn{3}{|l|}{ Antibiotic susceptibility } \\
\hline & & Sensitive & Intermediate & Resistant \\
\hline v9 & Vibrio fluvialis & $A Z M, C, C I P, C N, K, F, P B, S X T, T E$ & E & AMC, AMP \\
\hline V22 & Photobacterium damselae & AMP, AZM, C, CIP, F, PB, SXT, TE & $\mathrm{E}, \mathrm{CN}, \mathrm{K}$ & AMC \\
\hline V24 & V. parahaemolyticus & $A Z M, C, C I P, C N, K, F, P B, S X T, T E$ & E & $A M C, A M P$ \\
\hline V25 & Aeromonas hydrophila & AMC, AMP, AZM, C, CIP, CN, K, F, PB, SXT, TE & E & - \\
\hline V26 & V.parahaemolyticus & $A Z M, C, C I P, C N, K, F, P B, S X T, T E$ & E & AMC, AMP \\
\hline V27 & V. cholerae & AMC, AMP, AZM, C, CIP, E, CN, K, F, SXT, TE & - & PB \\
\hline V28 & V. vulnificus & $A Z M, C, C I P, E, C N, F, S X T, T E$ & K & AMC, AMP, PB \\
\hline V30 & Not identified & AMC, AMP, AZM, C, CIP, E, CN, K, F, PB, SXT, TE & - & - \\
\hline V31 & V. vulnificus & AMC, AMP, AZM, C, CIP, F, SXT, TE & $E, C N, K$ & PB \\
\hline V32 & V. azureus & AZM, C, CIP, F, PB, SXT, TE & $\mathrm{CN}, \mathrm{K}$ & AMC, AMP, E \\
\hline V33 & V. fluvialis & $C, C I P, C N, K, F, S X T, T E$ & $A Z M, E$ & AMC, PB \\
\hline V34 & V. parahaemolyticus & $A Z M, C, C I P, C N, K, F, P B, S X T, T E$ & E & AMC, AMP \\
\hline V35 & V.parahaemolyticus & $A Z M, C, C I P, E, C N, K, F, S X T, T E$ & - & AMC, AMP, PB \\
\hline V36 & Not identified & AMP, AZM, C, CIP, F, PB, SXT, TE & $E, C N, K$ & AMC \\
\hline V37 & V.xuii & $A Z M, C, C I P, C N, K, F, P B, S X T, T E$ & E & AMC, AMP \\
\hline V38 & V. azureus & $A Z M, C, C I P, C N, K, F, P B, S X T, T E$ & E & AMC, AMP \\
\hline
\end{tabular}

Amoxycillin (AMC), Ampicillin (AMP), Azithromycin (AZM), Chloramphenicol (C), Ciprofloxacin (CIP), Erythromycin (E), Gentamycin $(C N)$, Kanamycin (K), Nitrofurantoin (F), Polymyxin B (PB), Sulphamethoxazole (SXT), Tetracycline (TE).

Four isolates (V22, V32, V31, and V36) showed an intermediate sensitivity/resistance towards gentamycin, whereas the other $75 \%$ strains represented sensitivity against it (Table 4). Five strains exhibited resistance against polymyxin B. Only one strain (V32) was resistant to erythromycin but 11 strains showed intermediate sensitivity/resistance and the remaining four strains were found to be sensitive. The descending order of resistance patterns of studied strains was V28, V32, V35 (3 resistances) > V9, V24, V26, V33, V34, V37, V38 (2 resistances) > V22, V27, V31, V36 (1 resistance). Therefore, among 16 bacterial strains, 14 strains $(87.5$ $\%$ ) were resistant to at least one antibiotic. 


\begin{tabular}{llll}
\hline \multirow{2}{*}{ Name of antibiotics } & \multicolumn{2}{c}{ Isolates of Vibrio spp. $(\mathrm{n}=16)$} & $\mathrm{S} \%$ \\
\cline { 2 - 4 } & $\mathrm{R} \%$ & $\mathrm{l} \%$ & $4(25)$ \\
\hline Amoxycillin & $12(75)$ & $0(0)$ & $7(43.75)$ \\
\hline Ampicillin & $9(56.25)$ & $0(0)$ & $15(93.75)$ \\
\hline Azithromycin & $0(0)$ & $1(6.25)$ & $16(100)$ \\
\hline Chloramphenicol & $0(0)$ & $0(0)$ & $16(100)$ \\
\hline Ciprofloxacin & $0(0)$ & $0(0)$ & $4(25)$ \\
\hline Erythromycin & $1(6.25)$ & $11(68.75)$ & $12(75)$ \\
Gentamicin & $0(0)$ & $4(25)$ & $11(68.75)$ \\
Kanamycin & $0(0)$ & $5(31.25)$ & $16(100)$ \\
Nitrofurantoin & $0(0)$ & $0(0)$ & $11(68.75)$ \\
\hline Polymyxin B & $5(31.25)$ & $0(0)$ & $16(100)$ \\
\hline Sulphamethoxazole & $0(0)$ & $0(0)$ & $16(100)$ \\
\hline Tetracycline & $0(0)$ & $0(0)$ &
\end{tabular}

The resistance rates of studied isolates to amoxicillin, ampicillin, polymyxin B and erythromycin were found to be $75 \%, 56.25 \%, 31.25 \%$ and $6.25 \%$, respectively. A $100 \%$ sensitive response by the isolates was observed against nitrofurantoin, tetracycline, chloramphenicol, sulphamethoxazole and ciprofloxacin.

\section{Multiple antibiotic resistance (MAR) index of the studied strains}

Multiple antibiotic resistance (MAR) was observed for three studied strains viz V28, V32 and V35 which were identified as $V$. vulnificus, $V$. azureus and $V$. parahaemolyticus, respectively. MAR index value of these three isolates was 0.25 (Fig. 4).

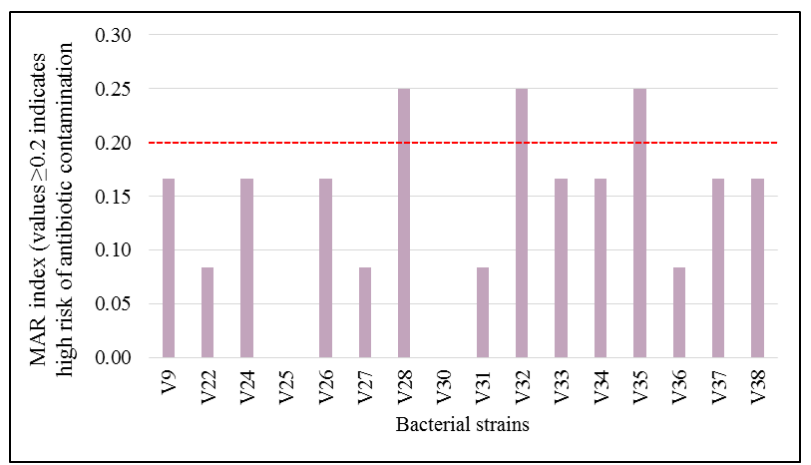

Fig. 4. Multiple antibiotic resistance (MAR) index values of 16 diversified bacterial isolates from Penaeus monodon farms against 12 antimicrobial agents.

\section{Discussion}

Classical approach of identification and characterisation of bacterial isolates is based on phenotypic traits from biochemical reactions that make the study of diverse Vibrio spp. difficult (Alsina and Blanch, 1994a, b); and has the disadvantage of the requirement of strains to grow and produce a detectable reaction. The use of 16S rRNA gene sequences has been considered as the solution to this problem. By phenotypic characterisation, Ransangan and Mustafa (2009) identified four bacterial isolates as $V$. harveyi, 16 as $V$. parahaemolyticus and one as $V$. alginolyticus, whereas $16 S$ ribosomal DNA sequencing showed all 21 isolates as $V$. harveyi. In this work, $16 \mathrm{~S}$ rDNA was applied to estimate the diversity of pathogenic Vibrio associated with tiger shrimp cultured in brackish waters of Satkhira and Bagerhat districts of Bangladesh. Among 16 isolates of the present study, 16S rRNA sequences of 14 isolates were identified as seven different bacterial species viz. V. fluvialis (V9,V33), P. damselae (V22), V. parahaemolyticus (V24, V26, V34, V35), V. cholerae (V27), V. vulnificus (V28, V31), V. azureus (V32, V38), V. xuii (V37) under Vibrionaceae family and one Aeromonas hydrophila (V25) under Aeromonadaceae family. Heenatigala and Fernando (2016) in one of their studies used 16S rDNA gene and identified only four Vibrio species viz., $V$. alginolyticus, $V$. parahaemolyticus, $V$. damselae and $V$. anguillarum, though more than 30 pathogenic Vibrio spp. have been identified in shrimp culture systems (Farmer III, 1992). Manilal et al. (2010) worked on the virulence of vibrios isolated from diseased black tiger shrimp and the isolated 29 distinct colonies were under six species including luminescent $V$. harveyi, $V$. alginolyticus, V. vulnificus, V. fischeri, V. parahaemolyticus, and P. damselae.

Felix et al. (2011) used 16S rDNA to identify Vibrio species and found that of seven strains of Vibrio sp. five were $97 \%$ homologues to $\mathrm{V}$. alginolyticus, $\mathrm{V}$. 
parahaemolyticus, V. harveyi, V. shilonii and $V$. vulnificus. Another two strains isolated in their study were not found to be homologous to any of the GenBank listed strain and therefore were considered as indigenous Vibrio spp. from Indonesia. Hagstrom et al. (2000) stated that isolates those shared greater than $97 \%$ similarities with the $16 S$ rDNA sequence may represent the same species. While the sequence similarities between 93-97\% can represent identity at the genus level but different at the species level. In our study, we have found 97.81 to $100 \%$ similarity of studied isolates with that of closest relatives obtained from NCBI GenBank.

Though popularly known to cause gastrointestinal illness in humans, $V$. parahaemolyticus is also one of the several causative agents of shrimp disease causing Acute Hepatopancreatic Necrosis Disease (AHPND) (Tran et al., 2013). This disease has gained much importance due to high mortality rates in the early stage of post larvae (PL) stocking resulting in severe production losses (Kongrueng et al., 2014). This bacterium also caused disease outbreak and mass mortalities in cultured Pacific white shrimp (Penaeus vannamei Boone, 1931) in the grow-out ponds of India under unfavourable environmental conditions (Kumar et al., 2014). Moreover, this bacterium was isolated from shrimp farms in India but was found AHPND negative (Paria et al., 2019). Vibrio parahaemolyticus was also found as dominant bacteria in infected shrimp facing red disease and tail necrosis (Jayasree et al., 2006). Vibrio cholerae causes cholera. Vibrio cholerae is being reported to be isolated from fish during cholera outbreaks and also isolated when there were no outbreaks as this bacteria are indigenous to marine waters (Feachem et al., 1981; cited in ICMSF, 2005). Species of the genus Vibrio are the most common bacterial agents in contaminated shellfish causing food poisoning (Levine et al., 1993; cited in ICMSF, 2005). Vibrio vulnificus is a human pathogen found in coastal environments. After $V$. parahaemolyticus, it is the second most common bacterial agent that causes food-borne infection and due to the high mortality, it poses significant health risk (Kushawaha et al., 2010). Vibrio vulnificus has also been found to be associated with loose shell syndrome (LSS) of shrimp with other Vibrio species (Jayasree et al., 2006). LSS was observed in all ages of shrimp with mortality rate reached $100 \%$ within 10 days of onset of infection. Vibrio fluvialis is another halophilic emerging foodborne human pathogen that is commonly found in coastal water (Liang et al., 2013). Vibrio fluvialis is also known to cause white faeces syndrome (WFS) in $P$. monodon (Kumara and Hettiarachchi, 2017). Vibrio azureus is a luminous marine bacterium, and still not recognised as shrimp pathogen though reported recently in India associated with running mortality syndrome (RMS) of P. vannamei (Alavandi et al., 2019). Considered as an environmental species, V. xuii has been isolated from shrimp culture environments (Thompson et al., 2003) and demonstrated either non- or low virulence in the aquatic animal models (Austin et al., 2005). Photobacterium damselae subsp. damselae is a marine bacterium under the family Vibrionaceae that is identified as an emerging pathogen of diverse aquaculture species, including fish, molluscs, and crustaceans. It was found in the internal organs of $P$. monodon and it showed pathogenicity to shrimp and also reported in the black gill diseased P. monodon in India (Vaseeharan et al., 2007). Aeromonas hydrophila infections are another major threat in commercial aquaculture and a large number of fish and shellfish species are very much prone to this infection. Bacterial diseases associated with Aeromonas in prawn are "black-spot" bacterial necrosis and gill obstruction (Lombardi and Labao, 1991a, b). Moreover, identified V. parahaemolyticus, V. cholerae and $V$. vulnificus were categorised as high risk vibrios whereas $V$. fluvialis and $P$. damselae as lower risk organisms in terms of zoonotic potential (Austin, 2010).

In the present study, chloramphenicol was found to be $100 \%$ sensitive to Vibrio isolates, but the scenario was opposite in Indian shrimp farms where all six Vibrio species showed $100 \%$ resistance, as chloramphenicol is highly used in India (Manilal et al., 2010). Heenatigala and Fernando (2016) used antibiotics to control the vibriosis diseases of shrimp and found that all Vibrio isolates were resistant to ampicillin, chloramphenicol, gentamycin, kanamycin, oxytetracycline and trimethoprim which are commonly used antibiotics in aquaculture. Vibrio parahaemolyticus isolated from $P$. vannamei shrimp cultured in low saline waters in India were found to be resistant to $\beta$-lactam antibiotics and cephalosporin (Sanathkumar et al., 2014). In the present study, several Vibrio species were found to be resistant to amoxicillin, ampicillin, erythromycin and polymyxin B.

MAR index values $\geq 0.2$ means that the bacterial strains were exposed to several antibiotics or isolated from contaminated sources, whereas, the strains with values $<0.2$ are less likely to be exposed to antibiotics (Noorlis et al., 2011). Lee et al. (2018) isolated 165 strains of $V$. parahaemolyticus from 240 fish samples (both freshwater and marine) in Malaysia. They discovered the antibiotic resistance patterns of those isolates and found that $70 \%$ were resistant to 3 to 8 types of antibiotics having MAR index values $>0.2$ (Lee et al., 2018). In a study on AMR and virulence genes of Vibrio strains isolated from ready-to-eat shrimps in Nigeria, Beshiru et al. (2020) found that $10.9 \%$ of $V$. parahaemolyticus were resistant to 18 antibiotics with a MAR index of 0.75 and $21.4 \%$ of $V$. vulnificus were resistant to 10 antibiotics with a MAR index of 0.42 . The present study supports the results of these previous research findings. Therefore, antibiotic resistance of Vibrio spp. is a potential barrier of controlling infectious diseases of aquatic animals as well as it is a global public health issue. 
Hossain et al. (2012) found the main reason for antibiotic resistance of Vibrio species was due to the indiscriminate use of antibiotics in shrimp farming of Bangladesh. Kumara and Hettiarachchi (2016) found varying degrees of antibiotic resistance among Vibrio species and recommend strict bio-security measures and best management practices to control the pathogenic vibrios. Moreover, the antibiotic resistance phenomenon is going to be a'slow-moving pandemic' that at least 700,000 people die each year globally (https://amr-review.org/), and the yearly death toll is predicted to rise to 10 million by 2050 which is higher than death toll caused by cancer today, as reported by Foreign Policy news (https://foreignpolicy.com/2020/05/21/china-farmsantibiotic-resistance-antimicrobial-amr/).

\section{Conclusion}

This study was conducted to check the presence of Vibrio species diversity in farmed shrimp in southwestern farming regions of Bangladesh. The study found several species of Vibrio that are potentially pathogenic to shrimp, as well as to human. Varying degrees of antimicrobial resistance were also observed among the isolated vibrios. Further investigations are needed to identify the risk factors that could trigger disease outbreaks in shrimp farms with Vibrio strains. Shrimp health surveillance programme should be implemented effectively to prevent disease outbreaks and will help to improve shrimp production in Bangladesh.

\section{Acknowledgements}

This study was funded by University Grants Commission of Bangladesh under research grants number: 6(78)/Agriculture (Life-40)/2016.

\section{References}

Alavandi, S.V., Muralidhar, M., Dayal, J.S., Rajan, J.S., Praveena, P.E., Bhuvaneswari, T., Saraswathy, R., Chitra, V., Vijayan, K.K., Otta, S.K. 2019. Investigation on the infectious nature of Running Mortality Syndrome (RMS) of farmed Pacific white leg shrimp, Penaeus vannamei in shrimp farms of India. Aquaculture 500:278-289. https://doi.org/10.1016/j.aquaculture.2018.10.027

Alsina, M., Blanch, A.R. 1994a. A set of keys for biochemical identification of environmental Vibrio species. Journal of Applied Bacteriology 76:79-85. https://doi.org/10.1111/j.13652672.1994.tb04419.x

Alsina, M., Blanch, A.R. 1994b. Improvement and update of a set of keys for biochemical identification of Vibrio species. Journal of Applied Bacteriology 77:719-721. https://doi.org/10.1111/j.13652672.1994.tb02824.x

APHA. 1998. Standard Methods for the Examination of Water and Wastewater. 20 $0^{\text {th }}$ Edition. American Public Health Association (APHA), Washington DC. 1325 pp.

Austin, B. 2010. Vibrios as causal agents of zoonoses. Veterinary Microbiology 140:310-317. https://doi.org/10.1016 /j.vetmic.2009.03.015
Austin, B., Austin, D., Sutherland, R., Thompson, F., Swings, J. 2005. Pathogenicity of vibrios to rainbow trout (Oncorhynchus mykiss, Walbaum) and Artemia nauplii. Environmental Microbiology 7:14881495. https://doi.org/10.1111/j.1462-2920.2005.00847.x

Beshiru, A., Okareh, O.T., Okoh, A.I., Igbinosa, E.O. 2020. Detection of antibiotic resistance and virulence genes of Vibrio strains isolated from ready-to-eat shrimps in Delta and Edo States, Nigeria. Journal of Applied Microbiology 129:17-36. https://doi.org/10.1111/jam.14590

Clarridge, J. E. 2004. Impact of 16S rRNA gene sequence analysis for identification of bacteria on clinical microbiology and infectious diseases. Clinical Microbiology Reviews 17:840-862. https://doi.org /10.1128/CMR.17.4.840-862.2004

CLSI. 2009. Performance Standards for Antimicrobial Disk Susceptibility Tests. Approved standard, $10^{\text {th }}$ Edition. CLSI document M02-A10. Clinical and Laboratory Standards Institute. Wayne, PA, USA. 53 pp.

Costa, R.A., Araujo, R.L., Souza, O.V., Vieira, R.H.S.F. 2015. Antibioticresistant Vibrios in farmed shrimp. BioMed Research International 2015:505914. https://doi.org/10.1155/2015/505914

Devi, R., Surendran, P.K., Chakraborty, K. 2009. Antibiotic resistance and plasmid profiling of Vibrio parahaemolyticus isolated from shrimp farms along the coast of India. World Journal of Microbiology and Biotechnology 25:2005-2012. https://doi.org/10.1007/s11274$\underline{009-0101-8}$

FA0. 2018. The state of world fisheries and aquaculture 2018 - Meeting the sustainable development goals. Food and Agriculture Organization of the United Nations (FAO), Rome, Italy. 210 pp.

FA0. 2019. FAO yearbook. Fishery and aquaculture statistics 2017. Food and Agriculture Organization of the United Nations (FAO), Rome, Italy. 80 pp.

Farmer III, J.J. 1992. The family of Vibrionaceae. In: The Prokaryotes: A handbook on the biology of bacteria: Ecophysiology, isolation, identification, applications, Balows, A., Trüper, H.G., Dworkin, M., Harder, W., Schleifer, K.H. (Eds.), Springer-Verlag, New York, pp. 2938-2951.

Feachem, R.G., Miller, C. Drasar, B. 1981. Environmental aspects of cholera epidemiology. II. Occurrence and survival of Vibrio cholerae in the environment. Tropical Disease Bulletin 78:865-880.

Felix, F., Nugroho, T., Silalahi, S., Octavia, Y. 2011. Molecular characteristics of Vibrio sp causing Black Tiger Prawn (Penaeus monodon) disease in Sumatra and Java shrimp ponds by $16 \mathrm{~S}$ rDNA sequencing. Journal of Agricultural Technology 7:679-694.

Gopal, S., Otta, S.K., Kumar, S., Karunasagar, I., Nishibuchi, M., Karunasagar, I. 2005. The occurrence of Vibrio species in tropical shrimp culture environments: implications for food safety. International Journal of Food Microbiology 102:151-159. https://doi.org/10.1016/j.ijfoodmicro.2004.12.011

Hagstrom, A., Pinhassi, J., Zweiefel, U.L. 2000. Biogeographical diversity among marine bacterioplankton. Aquatic Microbial Ecology 21:231-244. https://doi.org/10.3354/ame021231

Hasan, M.R. 2001. Nutrition and feeding for sustainable aquaculture development in the third millennium. In: Aquaculture in the Third Millennium, (eds. Subasinghe, R.P., Bueno, P., Phillips, M.J., Hough, C., McGladdery, S.E., Arthur, J.R.), pp. 193-219. NACA, Bangkok and FAO, Rome.

Heenatigala, P.P.M., Fernando, M.U.L. 2016. Occurrence of bacteria species responsible for vibriosis in shrimp pond culture systems in Sri Lanka and assessment of the suitable control measures. Sri Lanka Journal of Aquatic Science 21:1-17. https://doi.org/10.4038 /sljas.v21i1.7481

Hossain, M.A.R., Hasan, M.R. 2017. An assessment of impacts from shrimp aquaculture in Bangladesh and prospects for improvement. 
FAO Fisheries and Aquaculture Technical Paper No. 618. Rome. 96 pp.

Hossain, M.S., Aktaruzzaman, M., Fakhruddin, A.N.M., Uddin, M.J., Rahman, S.H., Chowdhury, M.A.Z., Alam, M.K. 2012. Antimicrobial susceptibility of Vibrio species isolated from brackish water shrimp culture environment. Journal of Bangladesh Academy of Science 36:213-220. https://doi.org/10.3329/jbas.v36i2.12964

Hudzicki, J. 2009. Kirby-Bauer disc diffusion susceptibility test protocol. American Society for Microbiology, Washington DC. 23 pp.

International Commission on Microbiological Specifications for Foods (ICMSF). 2005. Fish and fish products. In: Microorganisms in foods 6 . Microbial ecology of food commodities, Kluwer Academic/Plenum Publishers, New York, pp.174-249.

Jayasree, L., Janakiram, P., Madhavi, R. 2006. Characterization of Vibrio spp. associated with diseased shrimp from culture ponds of Andhra Pradesh (India). Journal of World Aquaculture Society 37:523-532. https://doi.org/10.1111/j.1749-7345.2006.00066.x

Jory, D. 2014. Status, issues, and perspectives of the global shrimp farming industry: Opportunities for U.S. shrimp producers. https://businessdocbox.com/Agriculture/67795814-Status-issuesand-perspectives-of-the-global-shrimp-farming-industry.html (Accessed 07 December 2020).

Kongrueng, J., Yingkajorn, M., Bunpa, S., Sermwittayawong, N., Singkhamanan, K., Vuddhakul, V. 2014. Characterization of Vibrio parahaemolyticus causing acute hepatopancreatic necrosis disease in southern Thailand. Journal of Fish Disease 38:957-966. https://doi.org/10.1111/jfd.12308

Krumperman, P. H. 1983. Multiple antibiotic resistance indexing of Escherichia coli to identify high-risk sources of fecal contamination of foods. Applied and Environmental Microbiology 46:165-170. https://doi.org/10.1128/AEM.46.1.165-170.1983

Kumar S., Stecher, G., Li, M., Knyaz, C., Tamura, K. 2018. MEGA X: Molecular evolutionary genetics analysis across computing platforms. Molecular Biology and Evolution 35:1547-1549. https://doi.org/10.1093/molbev/msy096

Kumar, B.K., Deekshit, V.K., Raj, J.R.M., Rai, P., Shivanagowda, B.M., Karunasagar, I., Karunasagar, I. 2014. Diversity of Vibrio parahaemolyticus associated with disease outbreak among cultured Litopenaeus vannamei (Pacific white shrimp) in India. Aquaculture 433:247-251. https://doi.org/10.1016/j.aquaculture.2014.06.016

Kumara, K.R.P.S., Hettiarachchi, M. 2016. Regular monitoring and controlling Vibrio- a critical bio-security measure for Sri Lankan shrimp (Penaeus monodon) hatcheries. Fish Pathology 51:S46-S53. https://doi.org/10.3147/jsfp.51.S46

Kumara, K.R.P.S., Hettiarachchi, M. 2017. White faeces syndrome caused by Vibrio alginolyticus and Vibrio fluvialis in shrimp, Penaeus monodon (Fabricius 1798)- multimodal strategy to control the syndrome in Sri Lankan grow-out ponds. Asian Fisheries Science 30:245-261. https://doi.org/10.33997/j.afs.2017.30.4.003

Kushawaha, A., Mobarakai, N., Cooper, M., Rose, K., Awasum, M. 2010. Necrotising fasciitis with Vibrio vulnificus: A limb threatening dermatologic complication following exposure to marine life. BMJ Case Reports 2010:bcr1120092478. https://doi.org/10.1136 /bcr.11.2009.2478

Lee, L-H., Ab Mutalib, N-S., Law, J.W-F., Wong, S.H., Letchumanan, V. 2018. Discovery on antibiotic resistance patterns of Vibrio parahaemolyticus in Selangor reveals carbapenemase producing Vibrio parahaemolyticus in marine and freshwater fish. Frontiers in Microbiology 9:2513. https://doi.org/10.3389/fmicb.2018.02513

Letchumanan, V., Chan, K-G., Lee, L-H. 2015. An insight of traditional plasmid curing in Vibrio species. Frontiers in Microbiology 6:735. https://doi.org/10.3389/fmicb.2015.00735
Levine, W.C., Griffin, P.M., the Gulf Coast Vibrio Working Group. 1993. Vibrio infections on the Gulf Coast: Results of first year of regional surveillance. The Journal of Infectious Diseases 67:479-483. https://doi.org/10.1093/infdis/167.2.479

Liang, P., Cui, X., Du, X., Kan, B., Liang, W. 2013. The virulence phenotypes and molecular epidemiological characteristics of Vibrio fluvialis in China. Gut Pathogens 5:6. https://doi.org/10.1186/17574749-5-6

Lightner, D.V. 1988. Diseases of cultured penaeid shrimp and prawns. In: Disease diagnosis and control in North American marine aquaculture, Sinderman, C.J., Lightner, D.V. (Eds.), Elsevier, Amsterdam, pp. 8-127.

Lightner, D.V. 1993. Diseases of cultured penaeid shrimps. In: Handbook of mariculture, McVey J.P. (Ed.), CRC, Boca Raton, pp. 393-486.

Lightner, D.V. 1996. A handbook of shrimp pathology and diagnostic procedures for disease of cultured penaeid shrimp. World Aquaculture Society, Baton Rouge, LA. 35 pp.

Lombardi, J.V., Labao, V.L. 1991a. Disease and conditioning factors of mortality in larval culture of prawn of the genus Macrobrachium. In proceedings of the 3rd Brazilian symposium on shrimp culture, pp. 401-408. Joao Pessoa, Paraiba, Brazil.

Lombardi, J.V., Labao, V.L. 1991b. Diseases and other factors leading to mortality in juveniles and adults belonging to the genus Macrobrachium. In proceedings of the 3rd Brazilian symposium on shrimp culture. pp. 409-419. Joao Pessoa, Paraiba, Brazil.

Manilal, A., Sujith, S., Selvin, J., Shakir, C., Gandhimathi, R. 2010. Virulence of Vibrios isolated from diseased black tiger shrimp, Penaeus monodon, Fabricius. Journal of World Aquaculture Society 41:331-341. https://doi.org/10.1111/j.1749-7345.2010.00375.x

Manjusha, S., Sarita, G.B. 2011. Plasmid associated antibiotic resistance in Vibrio isolated from coastal waters of Kerala. International Food Research Journal 18:1171-1181.

Noorlis, A., Ghazali, F.M., Cheah, Y.K., Zainazor, T.C.T., Wong, W.C. Tunung, R., Pui, C.F., Nishibuchi, M., Nakaguchi, Y., Son, R. 2011. Antibiotic resistance and biosafety of Vibrio cholerae and Vibrio parahaemolyticus from freshwater fish at retail level. International Food Research Journal 18:1523-1530.

Otta, S.K., Karunasagar, I., Karunasagar, I. 1999. Bacterial flora associated with shrimp culture ponds growing Penaeus monodon in India. Journal of Aquaculture in the Tropics 4:309-318.

Paria, P., Kunal, S.P., Behera, B.K., Mohapatra, P.K.D., Das, A., Parida, P.K., Das, B.K. 2019. Molecular characterization and genetic diversity study of Vibrio parahaemolyticus isolated from aquaculture farms in India. Aquaculture 509:104-111. https://doi.org/10.1016 li.aquaculture.2019.04.076

Patel, J.B. 2001. 16S rRNA gene sequencing for bacterial pathogen identification in the clinical laboratory. Molecular Diagnostics 6:313321. https://doi.org/10.2165/00066982-200106040-00012

Ransangan, J., Mustafa, S. 2009. Identification of Vibrio harveyi isolated from diseased Asian seabass Lates calcarifer by use of 165 ribosomal DNA sequencing. Journal of Aquatic Animal Health 21:150155. https://doi.org/10.1577/H09-002.1

Ruangpan, L., Kitao, T. 1991. Vibrio bacteria isolated from black tiger shrimp, Penaeus monodon Fabricius. Journal of Fish Diseases 14:383-388. https://doi.org/10.1111/j.1365-2761.1991.tb00836.x

Saitou, N., Nei, M. 1987. The neighbor-joining method: a new method for reconstructing phylogenetic trees. Molecular Biology and Evolution 4:406-425.

Sanathkumar, H., Ravi, C., Padinhatupurayil, S.B., Mol, M., Prasad, J.K., Nayak, B.B. 2014. Microbiological investigation of persistent mortalities in Litopenaeus vannamei grown in low saline waters in 
India. Journal of Aquatic Animal Health 26:154-159. https://doi.org $\underline{\text { /10.1080/08997659.2014.902875 }}$

Schwarz, S., Silley, P., Simjee, S., Woodford, N., van Duijkeren, E., Johnson, A.P., Gaastra, W. 2010. Editorial: assessing the antimicrobial susceptibility of bacteria obtained from animals. Journal of Antimicrobial Chemotherapy 65:601-604. https://doi.org /10.1093/jac/dkq037

Sudha, S., Mridula, C., Silvester R., Hatha, A.A. 2014. Prevalence and antibiotic resistance of pathogenic vibrios in shellfishes from Cochin market. Indian Journal of Geo-Marine Sciences 43:815-824.

Tamura, K., Nei, M., Kumar, S. 2004. Prospects for inferring very large phylogenies by using the neighbor-joining method. Proceedings of the National Academy of Sciences 101:11030-11035. https://doi.org /10.1073/pnas.0404206101

Thompson, F.L., Austin, B., Swings, J. 2006. The biology of vibrios. ASM Press, Washington DC. 423 pp. https://doi.org/10.1128/9781555815714 Thompson, F.L., Li, Y., Gomez-Gill, B., Thompson, C.C., Hoste, K., Vandemeulebroecke, G., Rupp, S., Pereira, A., De Bem, M.M., Sorgeloos, P., Swings, J. 2003. Vibrio neptunius sp. nov., Vibrio brasiliensis sp. nov. and Vibrio xuii sp. nov., isolated from the marine aquaculture environment (bivalves, fish, rotifers and shrimps). International Journal of Systematic and Evolutionary Microbiology 53:245-252. https://doi.org/10.1099/ijs.0.02447-0

Thornber, K., Verner-Jeffreys, D., Hinchliffe, S., Rahman, M.M., Bass, D., Tyler, C.R. 2020. Evaluating antimicrobial resistance in the global shrimp industry. Reviews in Aquaculture 12:966-986. https://doi.org /10.1111/raq.12367

Tran, L., Nunan, L., Redman, M.R., Mohney, L.L., Pantoja, R.C. Fitzsimmons, K.K., Lightner, V.D. 2013. Determination of the infectious nature of the agent of acute Hepatopancreatic necrosis syndrome affecting penaeid shrimp. Diseases of Aquatic Organisms 105:45-55. https://doi.org/10.3354/dao02621

Vaseeharan, B., Sundararaj, S., Murugan, T., Chen, J.C. 2007. Photobacterium damselae ssp. damselae associated with diseased black tiger shrimp Penaeus monodon Fabricius in India. Letters in Applied Microbiology 45:82-86. https://doi.org/10.1111/j.1472765X.2007.02139.x

Weisburg, W.G., Barns, S.M., Pelletier, D.A., Lane, D.J. 1991. 16S ribosomal DNA amplification for phylogenetic study. Journal of Bacteriology 173:697-703. https://doi.org/10.1128/JB.173.2.697$\underline{703.1991}$ 